\title{
ПЕРСПЕКТИВЫ ВЫЯВЛЕНИЯ НОВЫХ КРУПНООБЪЕМНЫХ ЗОЛОТОРУДНЫХ МЕСТОРОЖДЕНИЙ НА ЕНИСЕЙСКОМ КРЯЖЕ
}

\author{
Р. Х. Мансуров \\ Центральный научно-исследовательский геологоразведочный институт \\ цветных и благородных металлов (ФГУП ЦНИГРИ)
}

Поступила в редакцию 13 февраля 2018 г.

\begin{abstract}
Аннотация: статья посвящена исследованию новых золото-сульфидных рудопроявлений на Енисейском кряже. Рассмотрены геологические особенности эталонных золоторудных месторождений Енисейского кряжа и выделен объект-аналог для вновь выявленных рудопроявлений. По ряду признаков - существенно карбонатный состав вмещающих отложений, отсутствие четко проявленной метасоматической зональности, объемный вкрапленный рассеянный характер руд - в качестве объекта-аналога рассматривается Олимпиаднинское золото-сульфидное месторождение. Приводятся основные модельные прогнозно-поисковые признаки перспективных рудопроявлений и объекта-аналога, что может способствовать выявлению новых месторождений подобного muna.
\end{abstract}

Ключевые слова: Енисейский кряж, крупнообъемные золоторудные месторождения и проявления, прогнозно-поисковые признаки.

\section{PROSPECTS OF DETECTION OF NEW LARGE-VOLUME GOLD DEPOSITS WITHIN THE YENISEI RIDGE}

\begin{abstract}
Yenisei Ridge. Geological features of the etalon gold deposits are considered and an analogue object for newly identified ore occurrences is detected. On a number of characteristics including the carbonate composition of the ore-hosting sediments, the absence of a distinct metasomatic zonation, the voluminous disseminated character of the ores - the Olimpiadninskoe gold-sulphide deposit is considered as an analogue object. The main model forecasting and prospecting features of perspective ore occurrences and an analogue object are presented, that can help to identify new deposits of this type.
\end{abstract}

Key words: the Yenisei Ridge, large-volume gold deposits and ore occurences, forecasting and prospecting features.

\section{Введение}

В настоящее время актуальным является вопрос восполнения минерально-сырьевой базы золота, поскольку традиционные источники его добычи, к которым, прежде всего, относятся золото-кварцевые месторождения и богатые россыпи золота, практически полностью истощены. В этой связи взоры специалистов-геологов и недропользователей устремлены на выявление и изучение новых типов месторождений, которые могут ликвидировать отрицательный баланс между вовлечением новых объектов в эксплуатацию и отработкой известных еще со времен СССР месторождений.

На Енисейском кряже, где большинство разрабатываемых в настоящее время месторождений представлено золото-кварцевым типом (Советское, Эльдорадо, Аяхтинское, Васильевское и др.), а богатые россыпи золота отработаны еще в 20-м веке, вопросы расширения минерально-сырьевой базы золота весьма важны. При этом в регионе известны уникальные (Олимпиад- нинское) и крупные (Ведугинское, Попутнинское, Удерейское) золото-сульфидные, а также комплексные золото-сульфидно-кварцевые (Благодатное) месторождения, эксплуатация которых позволяет Красноярскому краю быть одним из лидеров РФ по добыче золота.

Ряд геологических признаков, в т.ч. объемы и запасы руд, характер и морфология золотоносных минерализованных зон и рудных тел, средние содержания золота, возможность открытой отработки, позволяет объединять некоторые золоторудные месторождения в группу «крупнообъемных» объектов. Последние, в понимании автора, характеризуются следующими основными параметрами: а) большие объемы и запасы руды, б) невысокие средние содержания золота - как правило, около 0,3-2,0 г/т, редко более. Возможность их рентабельной карьерной отработки находится в зависимости от геолого-экономической ситуации и ряда других факторов (административногеографическое положение, наличие развитой инфраструктуры, транспортное сообщение и др.). Кроме 
того, к основным параметрам крупнообъемного золотого оруденения относятся морфология рудных тел (линейно-изометричные штокверковые или штокверкоподобные минерализованные зоны и залежи) и глубина их залегания (не более 300 м).

Целью данной работы является выявление основных прогнозно-поисковых признаков золотой минерализации новых, недавно выявленных при поисковых работах ФГУП ЦНИГРИ, рудопроявлений Южное и Буреминское и их сопоставление с принятым в качестве эталонного месторождением, а также разработка модельных прогнозно-поисковых признаков исследуемых месторождений и проявлений, что может способствовать выявлению новых крупнообъемных золоторудных месторождений.

\section{Особенности локализации перспективных крупнообъемных рудопроявлений}

Рудопроявление Южное расположено в пределах Нижне-Чиримбинского золоторудно-россыпного узла Северо-Енисейского рудного района и контролируется зоной системы Ишимбинского регионального разлома (рис. 1). Главной отличительной особенностью рудопроявления является локализация в верхней части разреза углеродсодержащих терригеннокарбонатных отложений сухопитской серии среднего рифея (свиты аладьинская и карточки $\left.\left(\mathrm{R}_{2} a l+k r\right)\right)$. В структурном плане рудопроявление Южное приурочено к рудоконтролирующей зоне рассланцевания, представляющей собой вытянутую в субмеридиональном (СС3) направлении зону протяженностью более 4 км и шириной около 1,5 км [1]. Зона выделяется интенсивной тектонической проработкой, смятием, интенсивным рассланцеванием, кливажом, а также осложненной мелкой складчатостью высоких порядков и флексурными перегибами. Структурная позиция зоны определяется ее локализацией в области динамического влияния Ишимбинской системы глубинных рудоконтролирующих разломов (в 6 км восточнее системы) в узле пересечения разрывных нарушений двух основных направлений: 1) СС3 разрывы, сонаправленные Ишимбинской системе разломов; 2) диагонального СВ - вероятно, пострудные осложняющие нарушения. Узел пересечения разрывов приурочен к пологопадающему (30-40) восточному крылу антиклинальной складки первого порядка - Певунской горст-антиклинали.

Вмещающими золотоносную минерализованную зону рудопроявления являются углеродсодержащие терригенно-карбонатные отложения свит аладьинской и карточки объединенных, представленных известняками, мраморизованными известняками, известковистыми доломитами с прослоями углеродсодержащих известковисто-глинистых сланцев кварцкальцит-серицитового состава. Содержание углеродистого вещества незначительно и составляет не более $0,5 \%$.

Рудопроявление расположено в зоне развития хлорит-серицитовой субфации зеленосланцевой фации регионального метаморфизма при отсутствии на рассматриваемой территории интрузивных образований.

Гидротермально-метасоматические изменения выражены, главным образом, в широко проявленной в пределах всей зоны складчато-разрывных деформаций железо-магнезиальной карбонатизации, максимальные концентрации которой наблюдаются в пределах минерализованной зоны.

Крупнообъемная золоторудная минерализация представлена тонкой сульфидной вкрапленностью, достигающей 8-10\% в пределах минерализованной зоны. Сульфиды на $99 \%$ представлены мышьяковистым пиритом, содержащим тонкодисперсное золото (рис. 2). По данным опробования горных выработок минерализованная зона в первичных ореолах выявляется по содержаниям золота более 0,3 г/т, средняя ее мощность около 200 м. Зона представляет собой согласную залежь рассеянной сульфидной вкрапленности. Минерализованная зона четко выражена в слабоконтрастной аномалии золота во вторичных ореолах рассеяния. По данным анализа ICP-MS аномальное геохимическое поле (АГХП) золота сопровождается повышенными содержаниями во вторичных ореолах рассеяния $\mathrm{As}, \mathrm{W}, \mathrm{Sb}, \mathrm{Cu}, \mathrm{Co}$ и др. Примечательно, что с АГХП золота сопряжено аномальное поле марганца, вероятно, связанное с широко проявленной железомагнезиальной карбонатизацией.

В пределах минерализованной зоны выявлены эпицентры повышенных концентраций золота (более 1,0 г/т) мощностью в первые десятки метров, отвечающие потенциально рудным зонам. Последние характеризуются увеличением вкрапленности сульфидов до 8-10\%, а также присутствием кварцевых секущих жильно-прожилковых образований, распространенных весьма неравномерно. Содержания золота в пределах потенциально рудных зон по данным пробирного анализа в отдельных бороздовых пробах достигают 6,5 г/т.

Температурный режим формирования золотоносных образований соответствует $320-270^{\circ} \mathrm{C}$ для ранней золото-сульфидной минерализации и $250-230^{\circ} \mathrm{C}$ для поздних жил и прожилков [2].

Рудопроявление Буреминское расположено в заангарской части Енисейского кряжа, на северо-восточном фланге Южно-Енисейского рудного района и входит в состав Тужимского рудного узла (рис. 1).

Структурно-тектоническая позиция определяется положением в зоне сочленения двух крупных структур Енисейского кряжа - Центрального антиклинория и Ангаро-Питского синклинория, восточнее зоны Ишимбинской системы рудоконтролирующих разломов. В пределах рудопроявления устанавливается крупный разлом СС3 ориентировки, вероятно, являющийся оперяющим к Ишимбинской зоне разломов. По-видимому, важнейшими структурными элементами золотой минерализации являются поперечные СВ разрывные нарушения, к узлам сочленения которых с СС3 разломом и приурочена золотая минерализация (рис. 3). 


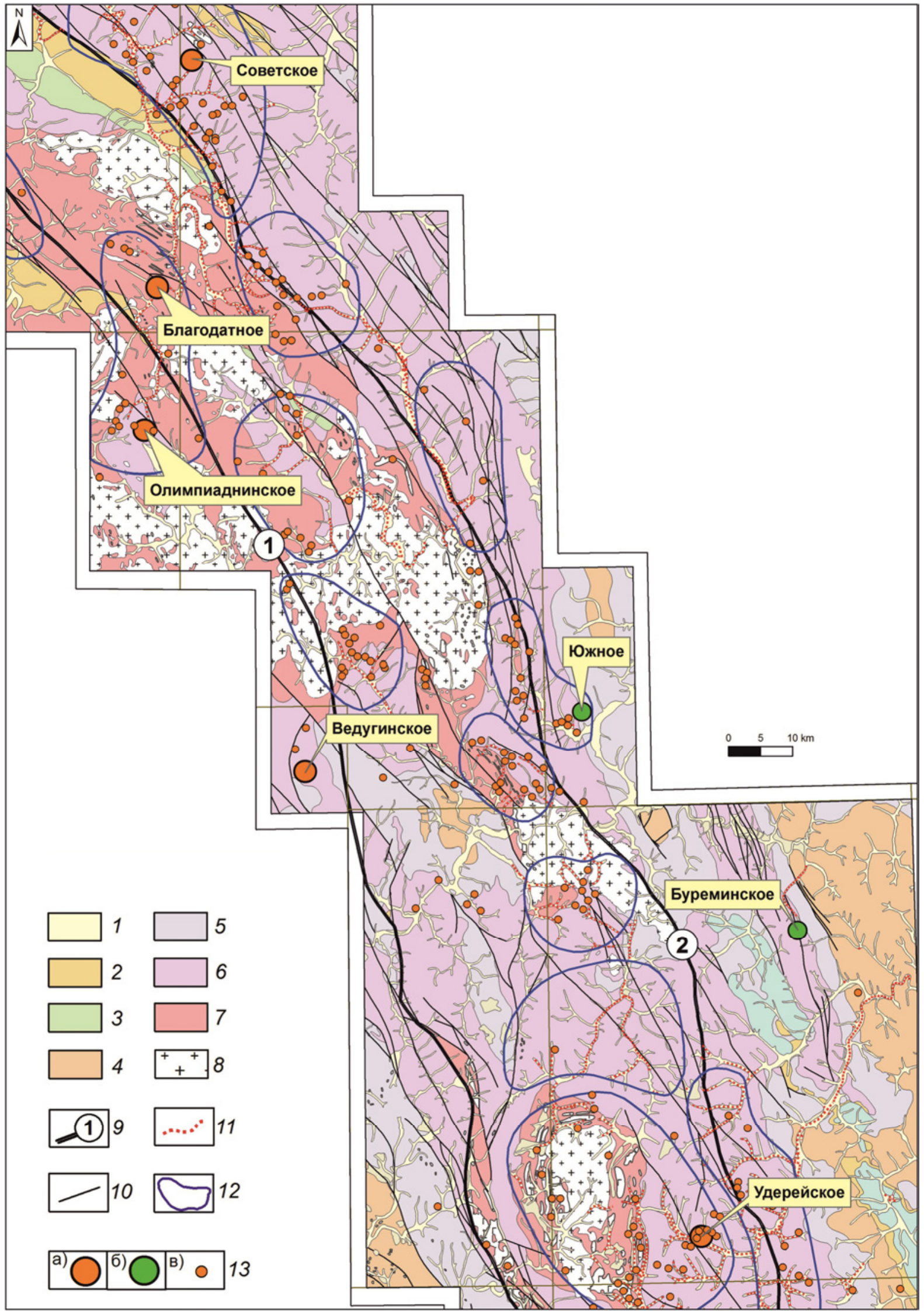

Puc. 1. Обзорная схема центральной и восточной частей Енисейского кряжа (с использованием данных ОАО «Красноярскгеолсъемка»): 1-7 - стратифицированные образования: 1 - четвертичные отложения; 2 - карбонатно-терригенный известковисто-доломито-алевритопесчанистый пестроцветный комплекс (немчанская (Vnm), подъемская ( $\mathrm{V} p d)$, суворовская 
$(\mathrm{V} s v)$, мошаковская $(\mathrm{V} m s)$, чистяковская ( $\mathrm{V} c v)$, алешинская (Val) свиты); 3 - карбонатно-терригенный известковистопесчано-алеврито-сланцевый комплекс (чивидинская $\left(\mathrm{R}_{3} c v\right)$, карьерная $\left(\mathrm{R}_{3} k r r\right)$, лопатинская $\left(\mathrm{R}_{3} l p\right)$ свиты); $4-$ флишоидный карбонатно-терригенный углеродсодержащий известковисто-песчано-сланцевый комплекс (сухохребтинская $\left(\mathrm{R}_{3} s h\right)$, горевская $\left(\mathrm{R}_{3} g r v\right)$, морянихинская $\left(\mathrm{R}_{3} m r\right)$, дашкинская $\left(\mathrm{R}_{3} d s\right)$, нижнеангарская $\left(\mathrm{R}_{3} n a\right)$, мокринская $\left(\mathrm{R}_{3} m k\right)$, рыбинская $\left(\mathrm{R}_{3} r b\right)$, бореминская $\left(\mathrm{R}_{3} b r\right)$, удоронская $\left(\mathrm{R}_{3} u d\right)$ свиты); 5 - углеродсодержащий карбонатно-терригенный доломито-известковистофиллито-песчано-сланцевый комплекс (шунтарская $\left(\mathrm{R}_{3} s n\right)$, потоскуйская $\left(\mathrm{R}_{3} p t\right)$, аладьинская $\left(\mathrm{R}_{2} a l\right)$, карточки $\left(\mathrm{R}_{2} k r\right)$ свиты; 6 - углеродсодержащий вулканогенно-карбонатно-терригенный туфогенно-известковисто-филлито-песчано-сланцевый комплекс (удерейская $\left(\mathrm{R}_{2} u d\right)$, горбилокская $\left(\mathrm{R}_{2} g r\right)$, кординская $\left(\mathrm{R}_{2} k d\right)$ свиты); 7 - карбонатно-терригенный кристаллосланцевый комплекс (пенченгинская свита $\left.\left(\mathrm{PR}_{2} p n\right)\right) ; 8$ - интрузивные образования: плагиогранодиоритовый комплекс (татарскоаяхтинский гранодиорит-плагиогранитовый $\left(\mathrm{R}_{3} t a\right)$, тейский гнейсогранитовый $\left(\mathrm{R}_{2} t e\right)$ ); 9-10 - разрывные нарушения: 9 региональные зоны разломов: а) Татарского, б) Ишимбинского; 10 - прочие; 11 - промышленные линейные россыпи золота (разведуемые, разрабатываемые, отработанные); 12 - контуры золоторудно-россыпных узлов; 13 - месторождения и проявления коренного золота: а) месторождения, принятые в качестве эталонных, б) перспективные рудопроявления, в) прочие.
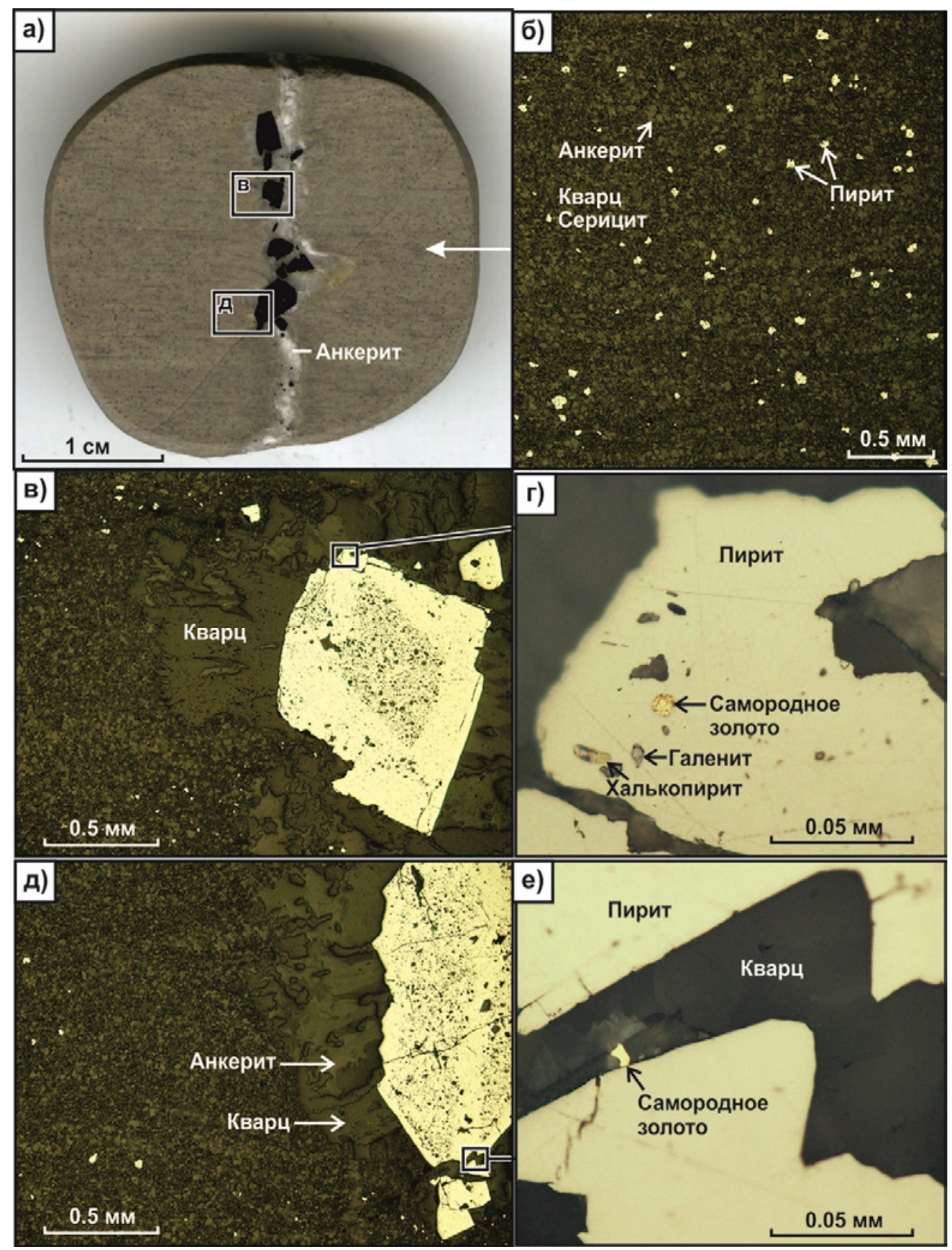

Рис. 2. Золото-сульфидная минерализация в анкерит-кварц-серицитовых сланцах: $a$ - анкерит-пирит-кварцевый прожилок, $\sigma$ - рассеянная вкрапленность пирита-1 во вмещающих сланцах, 6 -2 - сингенетичные включения халькопирита, галенита и самородного золота в кристалле пирита- $2, \partial-e-$ выделение самородного золота в кварце. 

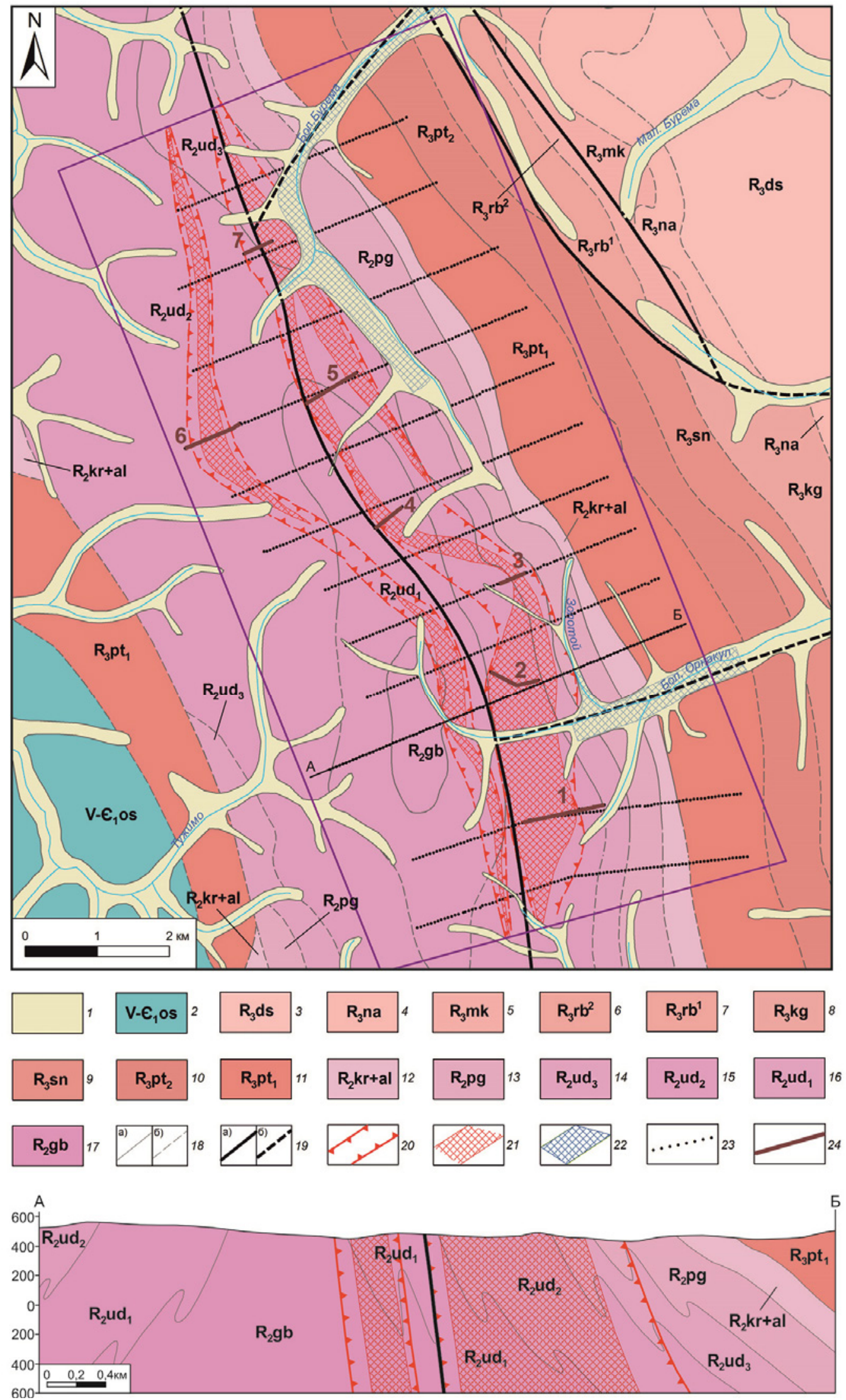

Puc. 3. Геологическая карта и разрез рудопроявления Буреминское: 1 - четвертичные отложения; 2-17 - стратифицированные отложения: 2 - островная свита: известковистые песчаники, доломиты, алевролиты; 3-17 - углеродистые карбонатно-терригенные отложения среднего-верхнего рифея: 3-4 - ослянская серия: 3 - дашкинская свита: известняки, мергели, 
аргиллиты, алевролиты, 4 - нижнеангарская свита: аргиллиты, алевролиты, кварцевые песчаники; 5-8 - киргитейская серия: 5 - мокринская свита: хлоритоидные сланцы с прослоями алевролитов, 6-7 - рыбинская свита: 6 - верхняя пачка: глинистохлоритоидные сланцы, 7 - нижняя пачка: глинистые сланцы, 8 - киргитейская серия нерасчлененная: известковистые аргиллиты, известняки; 9-11 - тунгусикская серия: 9 - шунтарская свита: углисто-глинистые сланцы, известняки, 10-11 потоскуйская свита: 10 - верхняя подсвита: сланцы алеврито-глинистые, песчаники, 11 - нижняя подсвита: красноцветные глинистые сланцы, алевролиты; 12-17 - сухопитская серия: 12 - свиты аладьинская и карточки объединенные: метадоломиты, метаизвестняки, сланцы серицитовые известковистые, 13 - погорюйская свита: сланцы алеврито-глинистые, прослои кварцитовидных песчаников, 14-16 - удерейская свита: 14 - верхняя подсвита: сланцы глинистые филлитизированные, 15 средняя посвита: сланцы серицит-хлоритовые, алевролиты, 16 - нижняя подсвита: сланцы глинистые, филлитовидные, алеврито-глинистые; 17 - горбилокская свита: кварц-хлорит-серицитовые сланцы, зеленовато-серые хлорит-серицитовые сланцы; 18 - геологические границы: $a$ - установленные, $\sigma$ - предполагаемые; 19 - разрывные нарушения: $a$ - установленные, $\sigma$ - предполагаемые; 20 - рудоконтролирующие зоны складчато-разрывных деформаций; 21 - золотоносные минерализованные зоны; 22 - промышленные россыпи золота; 23 - точки литохимического опробования по вторичным ореолам рассеяния (глубина 0,6 м); 24 - линии проходки копушей (глубина 1,0-1,2 м, интервал 40 м) с комплексом литохимического по вторичным ореолам рассеяния, шлихового, сколкового и штуфного опробования элювиально-делювиальных отложений.

Согласно ориентированная рудоконтролирующая зона складчато-разрывных деформаций (рассланцевания) рудопроявления Буреминское локализуется в углеродисто-терригенной толще удерейской свиты среднего рифея $\left(\mathrm{R}_{2} u d\right)$. Основными вмещающими породами являются отложения среднеудерейской подсвиты - карбонат-кварц-серицитовые (известково)алеврито-глинистые углеродсодержащие сланцы. Площадь работ амагматична - ближайший интрузивный массив выходит на поверхность в 16 км западнее рудопроявления.

Рудопроявление Буреминское приурочено к зоне развития хлорит-серицитовой субфации зеленосланцевой фации регионального метаморфизма с проявлением хлоритизации, мусковитизации, серицитизации и вновь образованных пирита, сидерита и других низкотемпературных минералов. Развитие хлорит-серицитовой субфации многими исследователями $[3,4]$ рассматривается в качестве благоприятной среды для промышленного золотого оруденения крупнообъемного (прожилково)-вкрапленного типа.

В пределах зоны рассланцевания широко распространены гидротермально-метасоматические процессы, главным образом, сульфидизация и железомагнезиальная карбонатизация. Последняя, наряду с сульфидизацией, является косвенном признаком, свидетельствующим о наличии золоторудного процесса [5]. Процессы (прожилково)-вкрапленной железо-магнезиальной и вкрапленной сульфидизации сопутствуют друг другу, образуя широкий (до 1 км) протяженный (до 10 км) ореол. Содержание карбонатов и сульфидов суммарно достигает 50-60 \%. Кварцевая жильно-прожилковая минерализация проявлена весьма неравномерно и наблюдается в основном в пределах наиболее минерализованных участков.

Золотоносная минерализованная зона, выявленная в пределах главной зоны рассланцевания, характеризуется невыдержанным извилистым строением (рис. 3). Мощность минерализованной зоны варьирует от 150 м в северной части участка, до 1300 м - в южной. Прослеженная протяженность достигает 10 км. Зона характеризуется сложным субсогласным линейноизометричным штокверкоподобным строением.

В пределах рудопроявления Буреминское выявлено два крупных АГХП золота - в северной и южной частях участка. Золотоносная минерализованная зона выделяется по содержаниям золота от 0,1 г/т в АГХП. Зона четко прослеживается в СС3 направлении, согласном простиранию вмещающих пород. Протяженность аномалий превышает 2 км, а мощность варьирует от 50 до 400 м. В пределах золотоносных минерализованных зон выявляются «стержневые» маломощные протяженные ореолы золота в ВОР с содержаниями более 0,3 г/т.

Среди сопутствующих элементов четко проявлены аномальные поля серебра в ВОР, приуроченные к периферийным участкам АГХП золота. Аномалии золота практически в точности совпадают с АГХП марганца. Природа последних, наиболее вероятно, связана с интенсивным развитием марганецсодержащей железо-магнезиальной карбонатизацией в пределах минерализованных зон.

По данным ООО «НПП ВИРГ-Рудгеофизика» 3оны гидротермально-метасоматических изменений рудопроявления Буреминское отвечают областям резкого ослабления интенсивности линейных магнитных аномалий и полного градиента магнитного поля - участки разрушения («распада») структуры магнитного поля. Наиболее вероятно, участки «распада» структуры магнитного поля связаны с разрушением в результате гидротермально-метасоматического преобразования осадочно-метаморфогенного магнетита (горбилокская свита) и пирротина (удерейская свита и др.).

\section{Типизация золоторудных}

\section{месторождений Енисейского кряжа}

Автором проведено исследование по выделению основных прогнозно-поисковых признаков эталонных золоторудных месторождений Енисейского кряжа, выполнен сравнительный анализ - результаты изучения приводятся в таблицах 1 и 2.

Месторождения золото-квариевого типа, в качестве эталонного объекта которых рассматривается Советское месторождение, характеризуются наличием секущих золотоносных жильных и жильнопрожилковых систем. Золото, как правило, находится в свободной форме, а его количество не зависит от степени проявления сульфидной минерализации [6]. 


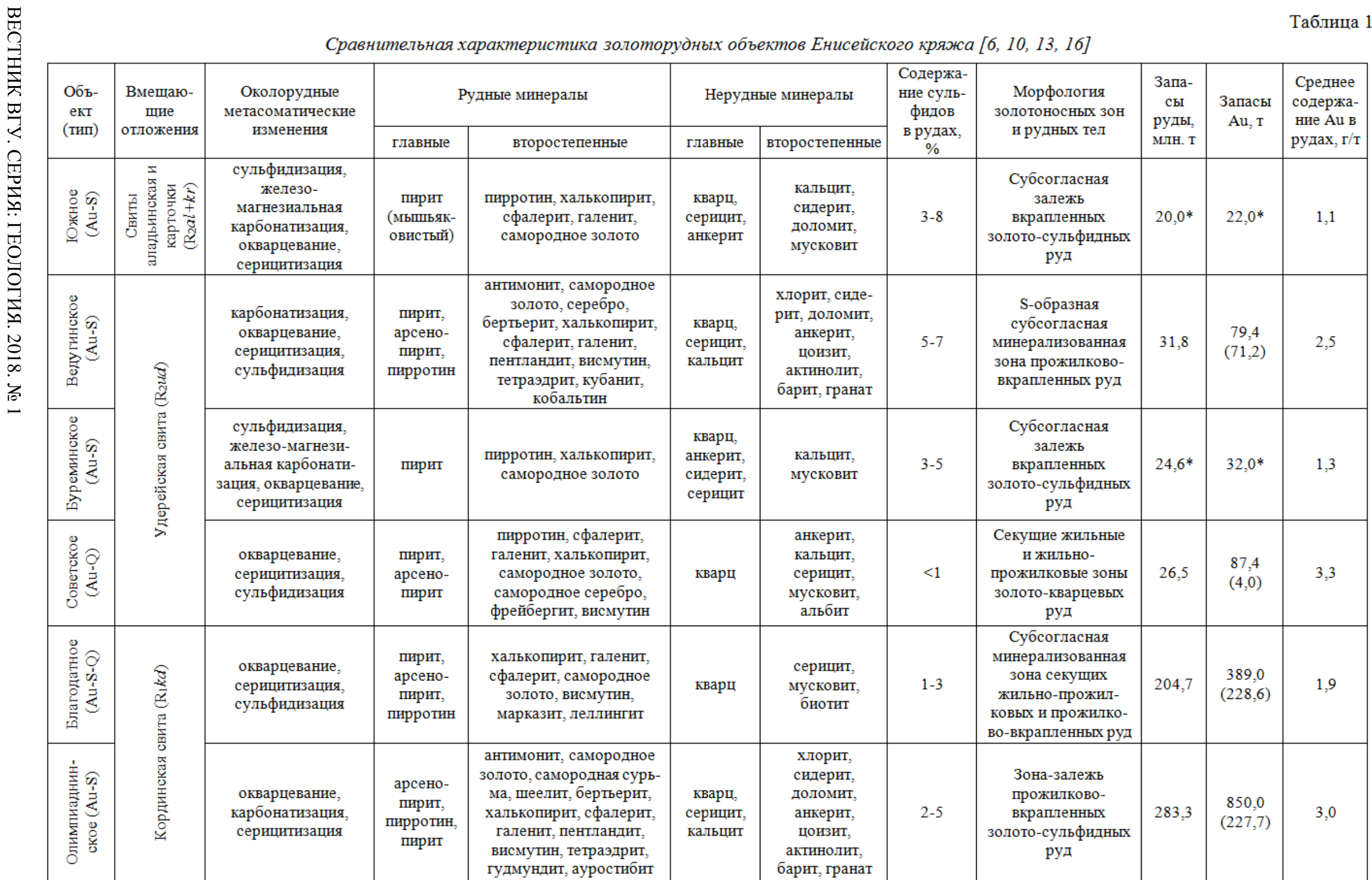

Примечание: в скобках указаны остаточные запасы; * - авторские данные прогнозных ресурсов; типы золоторудных объектов: Au-S - золото-сульфидный, Au-S-Q - золотоЕ сульфидно-кварцевый, $\mathrm{Au}-\mathrm{Q}-$ золото-кварцевый. 
Сопоставление прогнозно-поисковых критериев и признаков

Олимпиаднинского месторождения с рудопроявлениями Южное и Буреминское [1, 2, 10, 11, 13]

\begin{tabular}{|c|c|c|c|}
\hline $\begin{array}{l}\text { Прогнозно- } \\
\text { поисковые } \\
\text { критерии и } \\
\text { признаки } \\
\end{array}$ & $\begin{array}{c}\text { Олимпиаднинское } \\
\text { месторождение }\end{array}$ & $\begin{array}{c}\text { Южное } \\
\text { рудопроявление }\end{array}$ & $\begin{array}{c}\text { Буреминское } \\
\text { рудопроявление }\end{array}$ \\
\hline Тектонические & $\begin{array}{l}\text { Тейско-Татарская металлогеническая } \\
\text { зона, Енашимо-Верхне-Ерудинская } \\
\text { подзона }\end{array}$ & $\begin{array}{l}\text { Чернореченско-Каменская ме- } \\
\text { таллогеническая зона, Северо- } \\
\text { Енисейско-Ишимбинская } \\
\text { подзона }\end{array}$ & $\begin{array}{l}\text { Чернореченско-Каменская ме- } \\
\text { таллогеническая зона, граница } \\
\text { Северо-Енисейско-Ишимбинс- } \\
\text { кой и Ангаро-Питской подзон }\end{array}$ \\
\hline $\begin{array}{l}\text { Геолого- } \\
\text { структурные }\end{array}$ & $\begin{array}{l}\text { Зона геодинамического влияния Та- } \\
\text { тарского ССЗ разлома в узле сочле- } \\
\text { нения и пересечения разрывами суб- } \\
\text { широтной ориентировки; призамко- } \\
\text { вая часть Медвежинской антиклина- } \\
\text { ли; провис кровли гранитоидного } \\
\text { массива }\end{array}$ & $\begin{array}{l}\text { Зона геодинамического влияния } \\
\text { Ишимбинского СС3 } \\
\text { разлома в узле пересечения и } \\
\text { сочленения с разрывами СВ и } \\
\text { субширотной ориентировки; } \\
\text { восточное пологое крыло } \\
\text { Певунской антиклинали } \\
\end{array}$ & $\begin{array}{l}\text { Зона геодинамического влияния } \\
\text { Ишимбинского ССЗ } \\
\text { разлома в узле сочленения с } \\
\text { разрывами СВ ориентировки; } \\
\text { приядерная часть Ишимбинской } \\
\text { антиклинали }\end{array}$ \\
\hline $\begin{array}{l}\text { Литолого- } \\
\text { стратигра- } \\
\text { фические }\end{array}$ & $\begin{array}{l}\text { Углеродсодержащий карбонатно- } \\
\text { терригенный комплекс, кординская } \\
\text { свита }\left(\mathrm{R}_{1} \mathrm{kd}\right), \text { среднекординская под- } \\
\text { свита - слюдисто-кварц-карбонатные } \\
\text { сланцы с прослоями известняков }\end{array}$ & $\begin{array}{l}\text { Углеродсодержащий терригенно- } \\
\text { карбонатный комплекс, свиты } \\
\text { аладьинская и карточки }\left(\mathrm{R}_{2} \mathrm{al}+\mathrm{kr}\right)- \\
\text { карбонат-кварц-серицитовые } \\
\text { сланцы с прослоями углеродсо- } \\
\text { держащих известковисто- } \\
\text { глинистых сланцев }\end{array}$ & $\begin{array}{l}\text { Углеродсодержащий (вулкано- } \\
\text { генно)-карбонатно-терригенный } \\
\text { комплекс, удерейская свита } \\
\left(\mathrm{R}_{2} \mathrm{ud}\right), \text { среднеудерейская под- } \\
\text { свита - карбонат-кварц- } \\
\text { серицитовые углеродсодержа- } \\
\text { щие сланцы }\end{array}$ \\
\hline $\begin{array}{l}\text { Метамор- } \\
\text { фические }\end{array}$ & $\begin{array}{l}\text { Зона биотитовой ступени зеленослан- } \\
\text { цевой фации регионального мета- } \\
\text { морфизма, возрастающего до эпидот- } \\
\text { амфиболитовой фации }\end{array}$ & $\begin{array}{l}\text { Зона хлорит-серицитовой субфа- } \\
\text { ции зеленосланцевой фации ре- } \\
\text { гионального метаморфизма }\end{array}$ & $\begin{array}{l}\text { Зона хлорит-серицитовой суб- } \\
\text { фации зеленосланцевой фации } \\
\text { регионального } \\
\text { метаморфизма } \\
\end{array}$ \\
\hline $\begin{array}{l}\text { Гидротер- } \\
\text { мально- } \\
\text { метасома- } \\
\text { тические }\end{array}$ & $\begin{array}{l}\text { 1) высокотемпературные контактово- } \\
\text { метасоматические изменения (грейзе- } \\
\text { низация, скарнирование и др.); } \\
\text { 2) ореолы вкрапленной сульфидиза- } \\
\text { ции; } \\
\text { 3) околорудные изменения березито- } \\
\text { вого типа }\end{array}$ & $\begin{array}{l}\text { 1) ореолы вкрапленной сульфи- } \\
\text { дизации и прожилково- } \\
\text { вкрапленной железо-магнези- } \\
\text { альной карбонатизации; } \\
\text { 2) околорудные пирит-кварц- } \\
\text { серицитовые изменения }\end{array}$ & $\begin{array}{l}\text { 1) ореолы вкрапленной сульфи- } \\
\text { дизацции и железо- } \\
\text { магнезиальной карбонатизации; } \\
\text { 2) локальные околорудные } \\
\text { сульфидно-кварц-серицитовые } \\
\text { изменения }\end{array}$ \\
\hline $\begin{array}{l}\text { Минерало- } \\
\text { гические }\end{array}$ & $\begin{array}{l}\text { нерудные минералы - кварц, карбо- } \\
\text { наты, слюды (мусковит, серицит, } \\
\text { биотит), хлорит; } \\
\text { рудные минералы - арсенопирит, } \\
\text { пирротин, пирит, бертьерит, золото }\end{array}$ & $\begin{array}{l}\text { нерудные минералы - кварц, } \\
\text { серицит, карбонаты, хлорит; } \\
\text { рудные минералы - мышьякови- } \\
\text { стый пирит, редко пирротин, } \\
\text { халькопирит, золото } \\
\end{array}$ & $\begin{array}{l}\text { нерудные минералы - серицит, } \\
\text { карбонаты, кварц; } \\
\text { рудные минералы - пирит, ред- } \\
\text { ко пирротин, золото }\end{array}$ \\
\hline $\begin{array}{l}\text { Морфология } \\
\text { минерализо- } \\
\text { ванных зон и } \\
\text { рудных тел }\end{array}$ & $\begin{array}{l}\text { 1) крупнообъемная зона-залежь бед- } \\
\text { ных рассеянных вкрапленных пер- } \\
\text { вичных золото-сульфидных руд (до } \\
3,0 \text { г/т); } \\
\text { 2) золото-сурьмяные богатые (>3,0 } \\
\text { г/т) жильно-прожилковые зоны }\end{array}$ & $\begin{array}{l}\text { 1) крупнообъемная субсогласная } \\
\text { минерализованная зона-залежь } \\
\text { бедной }(0,3-1,0 \text { г/т) рассеянной } \\
\text { золото-сульфидной вкрапленно- } \\
\text { сти; } \\
\text { 2) маломощные секущие жильно- } \\
\text { прожилковые зоны с высокими } \\
\text { (до } 6,5 \text { г/т) содержаниями золота } \\
\end{array}$ & $\begin{array}{l}\text { 1) крупнообъемная минерализо- } \\
\text { ванная зона рассеянной суль- } \\
\text { фидной вкрапленности; } \\
\text { 2) маломощные жильно- } \\
\text { прожилковые секущие зоны }\end{array}$ \\
\hline $\begin{array}{l}\text { Минералого- } \\
\text { геохимичес- } \\
\text { кие }\end{array}$ & $\begin{array}{l}\text { 1) широкие слабоконтрастные АГХП } \\
\text { золота в ВОР и элементов-спутников } \\
\text { (сурьма, мышьяк, вольфрам); } \\
\text { 2) широкие слабоконтрастные шли- } \\
\text { ховые ореолы с тонким и мелким } \\
\text { золотом - первые десятки, редко сот- } \\
\text { ни знаков металла на шлиховую } \\
\text { пробу }\end{array}$ & $\begin{array}{l}\text { 1) широкие (до } 400 \text { м) АГХП } \\
\text { золота в ВОР }(0,01-0,1 \text { г/т); с } \\
\text { АГХП золота совмещены ано- } \\
\text { мальные поля мышьяка, марган- } \\
\text { ца; по периферии АГХП золота - } \\
\text { ореолы цинка; } \\
\text { 2) слабоконтрастные выдержанные } \\
\text { широкие шлиховые ореолы тонко- } \\
\text { го и мелкого золота; содержание } \\
\text { металла на шлиховую пробу - 3-5 } \\
\text { знаков, редко более в пределах } \\
\text { минерализованной зоны }\end{array}$ & $\begin{array}{l}\text { 1) широкие (до } 300 \text { м) АГХП } \\
\text { золота в ВОР с содержаниями } \\
0,01-0,1 \text { г/т; по периферии } \\
\text { АГХП золота - аномалии сере- } \\
\text { бра, марганца; } \\
\text { 2) широкие слабоконтрастные } \\
\text { шлиховые ореолы тонкого и } \\
\text { мелкого золота (0,1-0,6 мм) с } \\
\text { невысоким содержанием метал- } \\
\text { ла - 3-5 знаков на шлиховую } \\
\text { пробу в пределах минерализо- } \\
\text { ванной зоны }\end{array}$ \\
\hline $\begin{array}{l}\text { Геофизи- } \\
\text { ческие }\end{array}$ & $\begin{array}{l}\text { 1) положительные аномалии магнит- } \\
\text { ного поля; } \\
\text { 2) слабо отрицательные аномалии } \\
\text { поля силы тяжести }\end{array}$ & $\begin{array}{l}\text { 1) зона «распада» структуры } \\
\text { градиента магнитного поля - } \\
\text { слабо положительная аномалия; } \\
\text { 2) локальная отрицательная ано- } \\
\text { малия поля силы тяжести - ин- } \\
\text { трузивный гранитоидный массив } \\
\text { на глубине до } 2 \text { км? }\end{array}$ & $\begin{array}{l}\text { 1) зона «распада» структуры } \\
\text { градиента магнитного поля - } \\
\text { слабо положительная аномалия; } \\
\text { 2) слабо положительная анома- } \\
\text { лия поля силы тяжести }\end{array}$ \\
\hline
\end{tabular}


Характерной особенностью месторождений является наличие сближенных, сливающихся и ветвящихся жил, прожилков и сложных линз. Рудные тела состоят из кварцевых жил и прожилков, образующих залежи сложной морфологии с разделяющими их вмещающими породами. Количество кварца в рудных телах, в среднем, составляет $40 \%$, а количество сульфидов, как правило, не превышает $1 \%$. Пирит составляет около $80 \%$ сульфидных минералов, в подчиненном количестве проявлены пирротин и арсенопирит. Среди жильных зон часто обособляются мощные центральные части с существенно арсенопиритовой минерализацией; к флангам «тяготеет» рассеянная вкрапленность мелкокубического пирита [6]. Основное количество сульфидов приурочено непосредственно к кварцевым жилам и прожилкам; сульфидизация, как правило, проявлена в приконтактовых частях жильно-прожилковых образований или вблизи реликтов вмещающих пород в кварце $[7,8]$.

Месторождения золото-сульфидно-квариевого ти$n a$, в качестве эталонного объекта которых автором выделяется Благодатное месторождение, характеризуются совмещением жильно-прожилкового и прожилково-вкрапленного оруденения с образованием крупнообъемных штокверковых рудных тел с относительно равномерным содержанием золота в их пределах $[9,10]$.

Минерализованные зоны золото-сульфидно-кварцевых месторождений образованы сочетанием жильно-прожилковой и прожилково-вкрапленной минерализации. Руды этих месторождений, как правило, малосульфидные монометальные, прожилково-вкрапленные. Содержание сульфидов в рудах не превышает 3,0 \%, преобладают арсенопирит, пирротин, пирит, реже встречаются халькопирит, галенит, сфалерит, марказит, леллингит и др. [10].

Месторождения золото-сульфидного типа представлены такими крупными объектами, как Олимпиаднинское, Ведугинское месторождения. Они обладают рядом специфичных особенностей: золотосульфидный (прожилково)-вкрапленный характер руд, большие объемы и запасы руд и металла, отсутствие четко выраженной околорудной гидротермально-метасоматической зональности. При этом названные золото-сульфидные месторождения, объединяемые в одну группу, тем не менее, имеют ряд собственных отличительных признаков.

Так, хорошо изученное [7, 11-13] Олимпиаднинское месторождение большинством исследователей отнесено к золото-мышьяковисто-сульфидному типу, поскольку главным рудным минералом первичных руд является арсенопирит, заключающий тонкодисперсное золото. Рудовмещающая толща характеризуется существенно карбонатным составом, породы метаморфизованы в условиях биотитовой ступени зеленосланцевой фации регионального метаморфизма, возрастающего до эпидот-амфиболитовой фации вблизи интрузивного массива [12].

В рудах Олимпиаднинского месторождения выделяются несколько продуктивных минеральных ком- плексов: 1) прожилково-вкрапленный дорудный пиритпирротиновый, проявленный в пределах всего рудного поля; 2) основной продуктивный вкрапленный золотоарсенопиритовый (с тонкодисперсным золотом); 3) непостоянно продуктивный поздний вкрапленнопрожилковый золото-сурьмяный (бертьерит-антимонитовый) с относительно крупным самородным золотом [10-13]. Первые два типа формируют первичные бедные промышленные вкрапленные золото-сульфидные руды, а третий - богатые, наложенные золото-сурьмяные руды.

На Ведугинском месторождении крупнообъемное золотое оруденение месторождения образует минерализованную зону S-образной формы протяженностью около 2,7 км и шириной до 250 м. Рудные тела представляют собой метасоматиты серицитового, кварцсерицитового состава, к которым приурочены кварцевые и кварц-карбонатные прожилки, линзы и вкрапленная, реже прожилковая сульфидная минерализация. Основные рудные минералы: пирит (в том числе мышьяковистый), пирротин, арсенопирит. Содержание рудных минералов, как правило, не превышает 5$7 \%$. Степень золотоносности руд зависит от количества сульфидов [15].

Таким образом, месторождения золото-сульфидного типа, как правило, выделяются наличием многостадийного рудного процесса, совмещением нескольких типов золоторудной минерализации и комплексным составом руд. От известных золото-кварцевых и золото-сульфидно-кварцевых месторождений Енисейского кряжа золото-сульфидные объекты отличаются наличием (прожилково)-вкрапленных руд с низкими средними содержаниями золота (1-3 г/т), которые определяют крупнообъемный характер золотой минерализации и большие запасы руд и металла (табл. 1).

\section{Сопоставление с объектом-аналогом}

Сравнительный анализ позволяет выделить для вновь выявленных рудопроявлений Южное и Буреминское эталонный объект-аналог. По совокупности особенностей геологического строения, составу вмещающих пород, типу золотой минерализации, характеру и составу руд наиболее близким аналогом является месторождение Олимпиаднинское, а точнее его первичные ранние крупнообъемные вкрапленнорассеянные бедные золото-сульфидные руды.

В первую очередь следует отметить терригеннокарбонатный состав вмещающих отложений на сопоставляемых объектах и отсутствие четко выраженной метасоматической зональности. Вмещающими вкрапленные руды Олимпиаднинского месторождения являются измененные терригенно-карбонатные породы, сложенные карбонатами (преимущественно железистым кальцитом), кварцем и слюдами с примесью хлорита и углеродистого вещества. Минерализованную зону рассеянной сульфидной вкрапленности рудопроявления Южное вмещают существенно карбонатные измененные (серицитизация, железо-магнезиальная карбонатизация) породы - карбонат-серицито- 
вые сланцы, известняки с прослоями углеродсодержащих известковисто-глинистых сланцев. Золотоносность этих отложений нами установлена впервые ранее свиты аладьинская и карточки не рассматривались в качестве благоприятного вмещающего стратоуровня (рис. 4). Золотая минерализация рудопроявления Буреминское приурочена к карбонатсодержащим железо-магнезиально-карбонатизированным карбонат-кварц-серицитовым сланцам.

Рассматриваемые рудопроявления приурочены к областям развития низких ступеней зеленосланцевой фации регионального метаморфизма. На Олимпиаднинском месторождении большое распространение получили высокотемпературные контактовые образования, связанные с внедрением крупного гранитоидного массива. При этом на Олимпиадинском рудном поле вмещающие породы кординской свиты также претерпели низкотемпературный метаморфизм.

На площади рудопроявлений Южное и Буреминское интрузивные образования отсутствуют; ближайшие выходы гранитоидов татарско-аяхтинского комплекса находятся в 15-20 км от них. Однако, по данным ОАО «НПП ВИРГ-Рудгеофизика» отрицательная аномалия поля силы тяжести, фиксируемая в пределах рудопроявления Южное, может интерпретироваться как скрытый на глубине более 2 км крупный интрузивный массив.

Гидротермально-метасоматические изменения представлены объемными ореолами серицитизации, вкрапленной сульфидизации и прожилково-вкрапленной карбонатизации, в т.ч. железо-магнезиальной. Последняя, как правило, является благоприятным косвенным признаком золоторудного процесса [5]. На исследуемых рудопроявлениях аномальным литохимическим ореолам золота отвечают аномальные поля марганца, что, вероятно, связано с широким распространением железо-магнезиальной карбонатизации. Околорудные изменения, как правило, представлены жильно-прожилковыми зонами карбонат-кварц-серицитовых метасоматитов березитоидного типа.

Первичные вкрапленные руды Олимпиаднинского месторождения и золотую минерализацию рудопроявлений Южное и Буреминское объединяет тесная ассоциация золота с сульфидами (арсенопиритом и/или мышьяковистым пиритом), в которых оно находится в тонкодисперсной и субмикроскопической форме. Состав руд, как правило, полисульфидный. Главными рудными минералами являются пирит, арсенопирит, реже пирротин. Сульфидная минерализация всех рассматриваемых объектов обладает повышенной мышьяковистостью.

Все рассмотренные месторождения отличаются длительным полистадийным характером рудообразования, что фиксируется минералогическими наблюдениями, данными изотопной геохронологии и широким диапазоном температур гомогенизации флюидных включений.

При сопоставлении изотопно-геохимических данных обнаруживается, что золотоносные сульфиды
Олимпиаднинского месторождения и рудопроявления Южное обогащены тяжелым изотопом серы $\left(\delta^{34} \mathrm{~S}\right.$ от +3 до $+20 \%$ ), что может указывать на существенную роль гидротермально-осадочных процессов при формировании первичных рудных концентраций $[17,18]$. Это предположение подтверждается также и закономерным повышением доли тяжелого изотопа серы в рудах снизу вверх по разрезу вмещающих отложений сухопитской серии. При этом в ряду золоторудных объектов Енисейского кряжа рудопроявление Южное занимает наиболее высокое стратиграфическое положение и характеризуется максимальными значениями $\delta^{34} \mathrm{~S}=+14 . . .+17 \%$ [2]. Следует отметить, что по указанным изотопно-геохимическим особенностям золотоносной минерализации рудопроявление Южное можно сопоставить с месторождениями карлинского типа с существенно карбонатным составом рудовмещающих толщ, стратифицированным характером минерализованных зон и рудных тел, прожилково-вкрапленным оруденением, сульфидным составом руд с тонкодисперсными выделениями золота в сульфидах [19].

В то же время исследуемые рудопроявления характеризуется рядом специфических особенностей. Для рудопроявления Южное это, в первую очередь, положение в верхней части разреза сухопитской серии. Для обоих рудопроявлений характерно также отсутствие близко расположенных интрузивных массивов, локализация восточнее зоны Ишимбинского разлома, широкое развитие в пределах минерализованной зоны железо-магнезиальной карбонатизации.

\section{Заключение}

Среди рассмотренных золоторудных объектов Енисейского кряжа к группе крупнообъемных месторождений в первую очередь могут быть отнесены объекты золото-сульфидного типа, заключающие в себе большие запасы руд и металла. Однако по результатам геологоразведочных работ на месторождении Благодатное установлена возможность оконтуривания рудных тел по концентрациям золота в пределах единой крупнообъемной рудовмещающей минерализованной зоны с низкими (от 0,5 г/т) средними содержаниями золота [10]. На Советском месторождении при включении в контур оруденения слабозолотоносных вмещающих пород в межжильном пространстве оконтуривается единая крупнообъемная минерализованная зона мощностью около 300 м со средними содержаниями золота 1,0-1,5 г/т, пригодная для открытой отработки [6]. С учетом достаточно развитой инфраструктуры в районе месторождения такие параметры могут быть рентабельными.

Таким образом, к крупнообъемным месторождениям, помимо уникальных и крупных объектов золотосульфидного типа (Олимпиаднинское, Ведугинское, Удерейское), с учетом современных технологий переработки и обогащения руд, а также высокой цены на золото, могут быть отнесены месторождения комплексного золото-сульфидно-кварцевого (Благодатное) и даже золото-кварцевого (Советское) типов. 


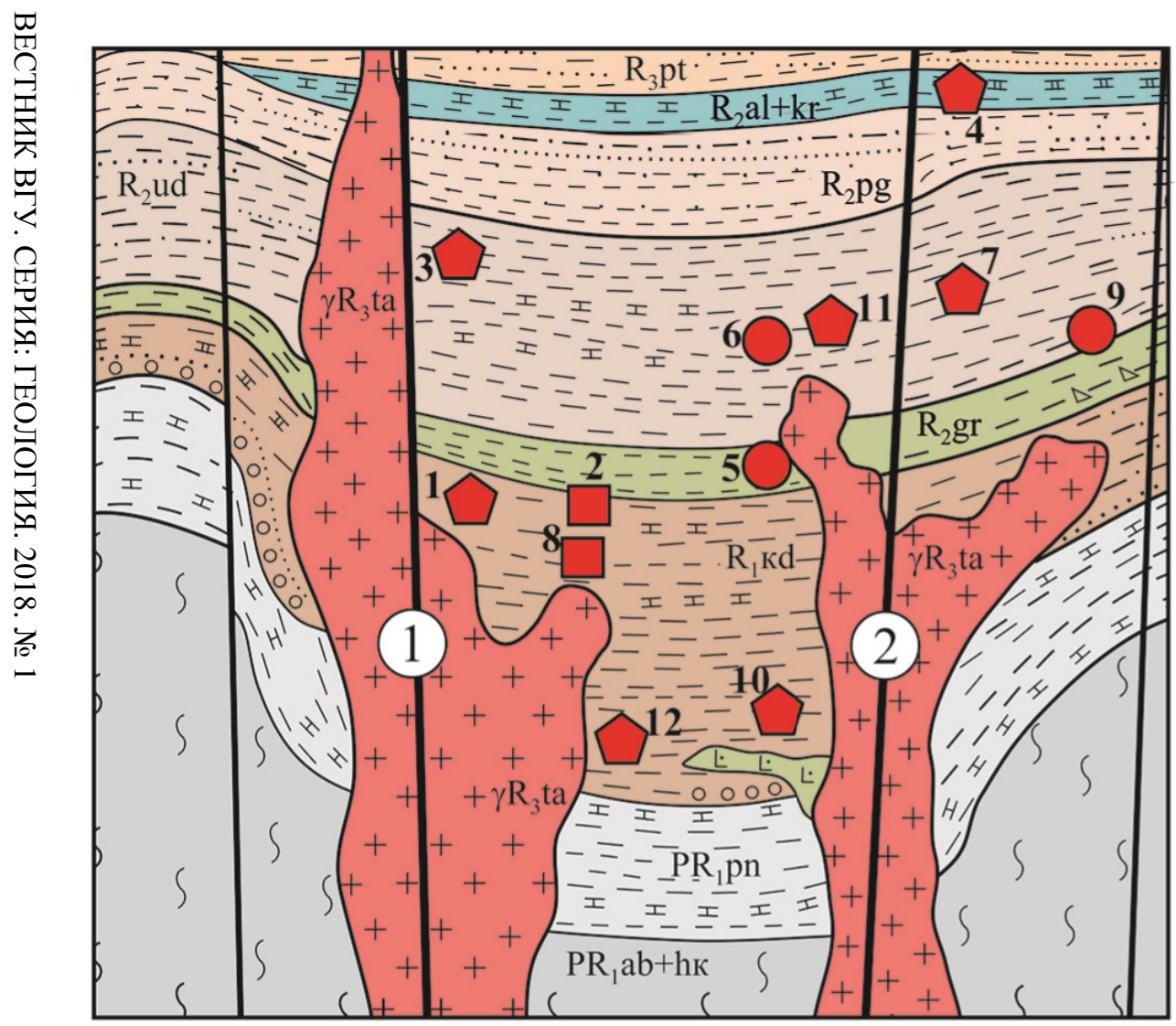

Золоторудные объекты:

1 - Олимпиаднинское,

2 - Благодатное, 3 - Ведугинское,

4 - Южное, 5 - Аяхтинское,

6 - Васильевское, 7 - Буреминское,

8 - Титимухтинское, 9 - Советское,

10 - Попутнинское, 11 - Удерейское,

12 - Раздолинское

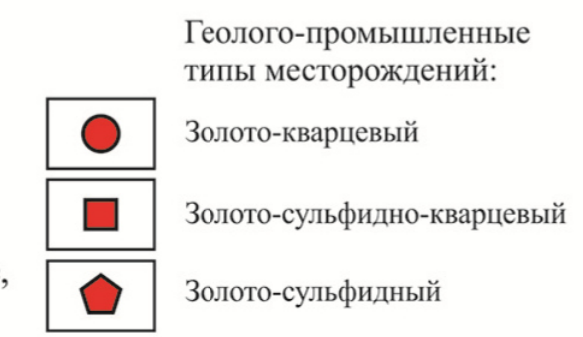

Стратифицированные образования:

-- Потоскуйская свита ( $\left.\mathrm{R}_{3} \mathrm{pt}\right)$ - карбонатно-терригенная глинистоалеврито-сланцевая

프 II II Аладьинская и карточки свиты объединенные $\left(\mathrm{R}_{2} \mathrm{al}+\mathrm{kr}\right)$ терригенно-карбонатная сланцево-доломит-известковистая

-._-_- Погорюйская свита $\left(\mathrm{R}_{2} \mathrm{pg}\right)$ - флишоидная песчано-сланцевая с фацией углеродистых сланцев;

- Удерейская свита $\left(\mathrm{R}_{2} \mathrm{ud}\right)$ - переслаивание серо-зеленых кварцхлорит-гидрослюдистых углеродсодержащих глинистых,

алеврито-глинистых и карбонатно-глинистых сланцев;

- - - Горбилокская свита ( $\mathrm{R}_{2} \mathrm{gr}$ ) - алеврито-глинистые, песчаноглинистые кварц-хлорит-серицитовые, кварц-серицитовые сланцы; Кординская свита ( $\left.\mathrm{R}_{1} \mathrm{\kappa d}\right)$ - углеродистые филлиты с невыдержанными прослоями кварцитовидных песчаников,

линзами туффитов, сланцы биотит-кварц-хлорит-серицитовые с гранатом;

Пенченгинская свита ( $\operatorname{Pr}_{1}$ pn) - зеленовато-темно-серые кварцхлорит-серицитовые, кварц-серицитовые сланцы углеродистые, рассланцованные эффузивы;

Свита хребта Карпинского и абалаковская толща (PR $a b+h \kappa)$ кристаллосланцевая, кристаллосланцево-гнейсовая с фациями амфиболитов, кварцитов и мраморов

\section{Интрузивные формации:}

Гранодиорит-гранитная (Татарско-Аяхтинский комплекс $\gamma \mathrm{R}_{3} \mathrm{ta}$ ) среднезернистые порфировидные граниты, гранодиориты;

Габбродолеритовая (Исаковский комплекс $v \mathrm{R}_{2}$ is) -

ортоамфиболиты, габбро-амфиболиты, амфиболизированные диабазы, аподиабазовые амфиболиты, амфиболовые сланцы.

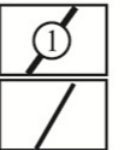

Региональные глубинные разломы:

1 - Татарский, 2 - Ишимбинский

Разрывные нарушения

Puc. 4. Схематический палеогеологический разрез Енисейской золоторудной провинции с размещением золоторудных месторождений и проявлений (по В. Д. Конкину с из๘ менениями и добавлениями). 
Проведенный сравнительный анализ и типизация золоторудных объектов позволяет выделить общие характерные геологические черты крупнообъемных золотосульфидных месторождений:

1) локализация в зонах крупных региональных рудоконтролирующих разломов;

2) комплексность и многоэтапность формирования руд с пространственным совмещением разновозрастного оруденения и преобразованием ранней золоторудной минерализации в ходе последующих процессов и гидротермальной деятельности;

3) приуроченность к областям развития низких ступеней зеленосланцевой фации регионального метаморфизма;

4) как правило, отсутствие четко выраженной гидротермально-метасоматической зональности;

5) наличие слабоконтрастных вторичных ореолов рассеяния золота и элементов-спутников;

6) объемный характер золотой минерализации и формирование (суб)согласных зон-залежей (прожилково)-вкрапленных рассеянных руд с наложенными секущими золото-кварцевыми жильно-прожилковыми образованиями.

Перспективы выявления новых крупнообъемных месторождений в углеродисто-карбонатно-терригенных комплексах Енисейского кряжа связаны с двумя главными факторами:

1) выявлением крупных гидротермально-осадочных систем с существенно золото-сульфидной вкрапленной минерализацией;

2) исследованием уже выявленных золото-кварцевых жильно-прожилковых систем с целью локализации «раннего» этапа крупнообъемной золотой минерализации, сопряженной с этими системами.

Рассматривая конкретные площади для постановки прогнозно-поисковых работ на крупнообъемное оруденение, в первую очередь, следует выделить участки, расположенные в пределах зоны Ишимбинского регионального разлома в восточной части Енисейского кряжа. К таковым относятся Тужимский, Нижне-Чиримбинский, Вангашский рудно-россыпные узлы. Выявление рудопроявления Южное расширяет также перспективы переоценки ареалов развития считавшихся ранее непродуктивными отложений верхов разреза сухопитской серии среднего рифея.

\section{ЛИТЕРАТУРА}

1. Мансуров, Р. Х. Минерализованные зоны рудопроявления Южное как пример высокого потенциала золотоносности восточного склона Енисейского кряжа / Р. Х. Мансуров // Вестник Воронеж. гос. ун-та. Сер. Геология. - 2016. - № 3. - С. 95-102. 2. Мансуров, Р. Х. Минералого-геохимические особенности рудопроявления Южное, Енисейский кряж / Р. Х. Мансуров, С. Г, Кряжев, Б. С. Зеликсон // Руды и металлы. - 2017. - № 1. C. 55-66.

3. Буряк, В. А. Метаморфогенно-гидротермальный тип промышленного золотого оруденения. / В. А. Буряк // Новосибирск:

Центральный научно-исследовательский геологоразведочный институт иветных и благородных металлов (ФГУП ЦНИГРИ), г. Москва

Мансуров Ринат Халитович, стариий научный сотрудник, кандидат геолого-минералогических наук

E-mail: rinman81@bk.ru; Teл.: 8-(495)-315-28-01
Наука, 1975. - 48 c.

4. Иванов, А. И. Роль метаморфизма в золотом рудообразовании в углеродистых терригенных и карбонатно-терригенных комплексах на примере Байкало-Патомской металлогенической провинции и его отражение в прогнозно-поисковых моделях / А. И. Иванов // Научно-методические основы прогноза, поисков и оценки месторождений благородных и цветных металлов состояние и перспективы: Сборник тез. докл. научно-практ. конф. М.: ЦНИГРИ, 2015. - С. 61-62.

5. Иванов, А. И. Золото Байкало-Патома (геология, оруденение, перспективы) / А. И. Иванов. - М.: ФГУП ЦНИГРИ, 2017. $-215 \mathrm{c}$.

6. Константинов, М. М. Золоторудные месторождения России / М. М. Константинов // М.: Акварель, 2010. - 349 с.

7. Неволько, П. А. Этапы формирования золотого и сурьмяного оруденения Енисейского кряжа и их корреляция с периодами проявления магматизма / П. А. Неволько, А. С. Борисенко // Металлогения древних и современных океанов. - 2009. - Т. 15. - C. 37-42.

8. Кряжев, С. Г. Генетические модели и критерии прогноза золоторудных месторождений в углеродисто-терригенных комплексах / С. Г. Кряжев // Автореферат дисс. докт. геол.-минер. наук. - Москва, 2017. $-52 \mathrm{c}$.

9. Полева, Т. В. Геология золоторудного месторождения Благодатное в Енисейском кряже / Т. В. Полева, А. М. Сазонов // М.: Экономическая газета, 2012. - 290 с.

10. Геологическое строение золоторудных месторождений и опыт геологического обслуживания сырьевой базы компании «Полюс» в Красноярском крае / В. К. Совмен [и др.]. - Красноярск: Полюс, 2009. - 208 с.

11. Ли, Л. В. Олимпиаднинское месторождение вкрапленных золото-сульфидных руд / Л. В. Ли // Красноярск: КНИИГиМС, 2003. $-119 \mathrm{c}$.

12. Новожилов, Ю.И. Золото-сульфидные месторождения в углеродисто-терригенных толщах / Ю.И. Новожилов, А.М. Гаврилов // М.: ЦНИГРИ, 1999. - 175 с.

13. Модели месторождений золота Енисейской Сибири / С.С. Сердюк [и др.]. - Красноярск: Сибирский федеральный университет, 2010. $-584 \mathrm{c}$.

14. Ножкин, А. Д. Этапы позднепротерозойского магматизма и возрастные рубежи золотого оруденения Енисейского кряжа / А. Д. Неволько, А. С. Борисенко, П. А. Неволько // Геология и геофизика. - 2011. - Т. 52. - № 1. - С. 158-181.

15. Сазонов, А. М. Ведугинское золото-сульфидное месторождение (Енисейский кряж) / А. М. Сазонов, А. Э. Романовский, Г. И. Шведов // Руды и металлы. - 1994. - № 2. - С. 86-97.

16. Государственный доклад «О состоянии и использовании минерально-сырьевых ресурсов Российской Федерации в 2015 году». - М.: Центр «Минерал», 2016. - 342 с.

17. Кряжев, С. Г. Изотопный состав и источники серы золотосульфидных месторождений Енисейского кряжа / С. Г. Кряжев, В. А. Гриненко // XVIII Симпозиум по геохимии изотопов имени академика А.П. Виноградова. Тезисы докладов. - М.: ГЕОХИ РАН, 2007. - С. 141-142.

18. Кряжев, С. Г. Изотопно-геохимические и генетические модели золоторудных месторождений в углеродистотерригенных толщах/ С. Г. Кряжев // Отечественная геология. 2017a. - № 1. - C. 1-11.

19. Константинов, М. М. Золоторудные месторождения типа карлин и критерии их выявления / М.М. Констанитинов // Руды и металлы. - 2000. - № 1. - С. 70-76.

Central Research Institute of Geological Prospecting for base and precious metals (FSUE TsNIGRI), Moscow

Mansurov R. Kh., Senior research scientist, Candidate of the

Geological and Mineralogical Sciences

E-mail: rinman81@bk.ru

Tel.: 8-(495)-315-28-01, 8-926-586-21-21 